\title{
Dear Professor, Be Careful with Those Tweets, OK? Academic Freedom and Social Media
}

Gloria C. Cox, University of North Texas

ABSTRACT As faculty members, we rely on academic freedom to protect us as we teach, engage in scholarly research, and live as citizens of a community. The American Association of University Professors is the accepted authority in matters of academic freedom, and its guidelines explain protections in teaching, research, and extramural utterances. This article argues that the characteristics of social media and the concerns of academic institutions about their reputation have created an atmosphere that make extramural utterances more vulnerable and riskier than in the past. Some institutions even monitor the social media postings of faculty members and act on such postings, openly criticizing and even disavowing or punishing them for their utterances. I consider these issues and make a modest proposal that may improve the environment for extramural utterances by faculty members.

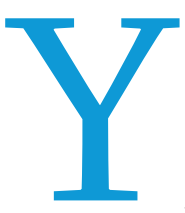
ou do a great job telling your class about the Supreme Court's ruling in McCulloch v. Maryland. No problem. You continue your research on human trafficking and send your latest paper off to a good journal, hoping for publication. No problem. Later in the day, you fire off a message on Twitter (or Facebook, Instagram, YouTube, or Snapchat) about the war in Afghanistan, the latest school shooting, or something the president has done. Problem-or at least the potential for one. As members of the professoriate, we rely on academic freedom to protect us as we teach our classes and conduct our research. But what about the comments we make outside of those two arenas, those we make as citizens? Does academic freedom have what it takes to protect us as technology changes and social media exercises such powerful control on communication? That question is the focus of this article.

\section{A BRIEF SUMMARY OF ACADEMIC FREEDOM}

Academic freedom is an important concept with roots in Colonial America and, before that, in European universities. Its existence and importance have been recognized by American courts and, for slightly more than a century, the American Association of University Professors (AAUP) has accepted the role of formulating principles and investigating cases in which academic freedom appears to have been violated. Academic freedom does not exist in a vacuum, of course, and so it has ebbed and flowed with changes in the greater society. The concerns of the early

Gloria C. Cox (1) is associate professor of political science at the University of North Texas. She can be reached at Gloria.Cox@unt.edu. twentieth century, with distrust of immigrants and fear of communists, gave way in later decades to marches for civil rights and against the war in Vietnam. Even the dangerous tactics of Senator McCarthy dissipated with time, although not without harm. The history of free expression in the twentieth century, including freedom on America's college and university campuses, is a fascinating and engaging story, told well by Chemerinsky and Gillman (2017) in their notable book, Free Speech on Campus.

As defined by the AAUP, there are three aspects to academic freedom: freedom in research, freedom in teaching, and freedom exercised as a citizen. The AAUP's 1940 Statement of Principles of Academic Freedom and Tenure considers the nuances of each, noting that "Teachers are entitled to full freedom in research and in the publication of the results, subject to the adequate performance of their other academic duties..." and "Teachers are entitled to freedom in the classroom in discussing their subject..." (AAUP 1940). The third category of freedom-utterances that are neither research nor teaching but instead comments made as a citizen-is called extramural utterances, about which the AAUP Statement says, "College and university teachers are citizens, members of a learned profession, and officers of an educational institution. When they speak or write as citizens, they should be free from institutional censorship or discipline..." (AAUP 1940). Clearly, the AAUP recognizes that there are times when faculty members are speaking privately as members of the greater community rather than in the classroom or research setting, and that those utterances are protected by the First Amendment right to free expressionsubject, of course, to established legal limits. Well, that certainly 
sounds straightforward enough but, of course, "the devil is in the details," and changing technology has made the issue even more complicated.

\section{THE NEWEST TOOL: SOCIAL MEDIA}

I argue that social media has changed the playing field for academic freedom, especially concerning extramural utterances. The Merriam-Webster Dictionary (2019) defines social media as "forms of electronic communication (such as websites for social networking and microblogging) through which users create online communities to share information, ideas, personal messages, and other content (such as videos)." In essence, social media enables people to connect with one another around the world, almost instantly, without intermediaries. According to the Pew Research Center, Facebook is the dominant form of social media for about two thirds of Americans (Smith and Anderson 2018). Moreover, they are using it a great deal, with " $74 \%$ of Facebook users saying they go on Facebook every day and $51 \%$ saying they log on several times a day" (Smith and Anderson 2018). Every minute, Facebook is accessed an astonishing 900,00o times (Briegas and Perez 2018). In addition to Facebook, there are YouTube, Snapchat, Instagram, and Twitter, and about " $42 \%$ of online adults" access multiple social-networking sites (Whiteman 2015). Social media is powerful, to the point that it has wrought a revolution in communication.

\section{ANALYZING THAT REVOLUTION}

Each new generation of mass communication brings powerful tools that people can use for whatever purpose-neutral, positive, or negative-whether it is the radio as used by Franklin Roosevelt (positively) and Adolf Hitler (negatively) or the television, which brought the Vietnam War into people's homes. We should wonderful or dreadful, accurate or inaccurate-compose a message, and decide if, when, and where to post it with no moderating influence to determine the usefulness or appropriateness of the message. We have become accustomed to bizarre content, poor grammar, hateful ideas, and all manner of invective posted on the whim of one person with no professional journalist between that person and their post.

Such instant postings therefore are lacking in the ethical considerations that professional journalists bring to every story, making it possible for any individual-from the erudite to the less knowledgeable-to post messages of their choosing, to become a journalist of a sort, at least in their own mind. Professional journalists, however, abide by their Code of Ethics, which includes a commitment to accuracy, identification of sources, avoidance of stereotyping, and balancing the rights of people and groups. Their code of behavior comes under such major headings as "Seek truth and report it, minimize harm, act independently, and be accountable and transparent" (Society of Professional Journalists 2014). Those who post on social media are not bound by any such code, which allows their behavior to range across many levels. There also is the likelihood of harm to professional journalists and journalism because most members of the public do not or cannot distinguish among different types of messages (which is a topic for another discussion).

Such postings not only travel the world in record time, they also do not limit the number of people who may see a post without any regard for whether it is accurate, well intentioned, or terribly misguided. A professor's casual post about the President of the United States, how a region is surviving a hurricane, and any of millions of other topics can paint not only individuals in a poor light but also their institution. Add to that the fact that a

\section{A professor's casual post about the President of the United States, how a region is surviving a hurricane, and any of millions of other topics can paint not only individuals in a poor light but also their institution.}

not be surprised, therefore, when new technologies result in their own transformations. However, I argue that this tool is more powerful than others, with the potential for transforming government and even society-including across international boundaries.

I argue that this is the first technology with the capability of reaching every person in the world with Internet access-and to do so almost instantly-including not only the informed with something worthwhile to say but also the ambitious, the haters, the manipulators, and the criminals. It also is distinctive in that there literally is no one-only technology-between the person and the message. Social media is driven by individuals rather than media professionals, which separates it from the gatekeepers existing in newspapers, radio, and television who make decisions about whether a particular message will be published or broadcast. Reporters conduct interviews, radio and television stations participate in investigations, and journalists ferret out facts about issues of interest. Absolutely none of this exists with social media so that in a matter of minutes (seconds?), a person can have an idea-however group-large or small, reputable or not, anywhere in the worldcan use the faculty member's message for its own purposes, from agreeing with it to denouncing it to manipulating it in some way. In an instant, the message is sent to tens of thousands of people with the group's message about how to interpret what has been posted. These messages are left online forever to be harvested for whatever purpose anyone wishes, which may have nothing to do with the original sender's intentions (Whittington 2019).

Some might argue that there is nothing wrong with a free marketplace of ideas from which individuals can choose, but that is hardly the reality of social media. A common outcome is that people find their way to harmful sites, including those of dictatorial regimes, terrorist recruiters, scammers, schemers, and manipulators. Perhaps, some would say, this is simply the collateral damage of such an accessible system. A second more pervasive outcome that is currently receiving considerable attention is the proclivity of social media to direct participants to sites that support and reinforce the views they already hold. Such sites lead participants to believe that many others, perhaps even a majority, hold the same views they 
do and that other views are simply wrong. Scholars have suggested that this practice is at least partly responsible for harmful effects against our political system.

This phenomenon is referred to as "cocooning" in so-called filter bubbles or echo chambers, so that people are "exposed primarily to ideologically congenial political information" (Eady et al. 2019). Scholars have begun to study the effects of these filter bubbles and have concluded that polarization is the primary effect (Spohr 2017). We have long known that Americans gravitate to network news sources that are compatible with views that they already hold, and that the effect of informing someone that they are mistaken is to cause the hearer to double-down on their beliefs, however mistaken or uninformed they may be. For a majority of Americans (62\%) (Spohr 2017) obtaining their news from social media, the implications of these filter bubbles are clear.

It is in this setting that members of the academic community use social media. Like others, they express their views on matters of importance to them, which-according to guidelines set forth by the AAUP-they are entitled to do.

\section{THE SPECIAL OBLIGATIONS OF UNIVERSITY FACULTY MEMBERS}

Academic freedom is a complicated matter, woven into the fabric of free speech in the more general sense. Although this article is primarily about the extramural utterances of faculty members on social media, it is useful to know that there are more general utterances that have resulted in faculty members being placed on leave, investigated, and even stripped of tenure and their faculty position. In other research, I found that the actions of faculty members that landed them in trouble fall into one or more of the following six categories:

- utterances construed to be racist

- utterances construed to be sexual harassment

- utterances in conflict with the institution

- utterances on matters of public policy

- utterances about which students made complaints

- utterances that attracted the attention of outside groups

Although not all of these offenses and the individuals who committed them were in the category covered by this article-that is, extramural utterances made on social media-the categories provide a context for understanding these issues. With the caveat that only some cases come to light, we nonetheless can see that institutions are monitoring the comments and actions of faculty members. What we cannot discern from the available data, unfortunately, is the extent of the monitoring-how many universities, how extensive the monitoring, and the number of faculty whose comments are acted on in some way by their institution. That such monitoring exists, however, is well established.

\section{AAUP: "THEY SHOULD BE FREE FROM INSTITUTIONAL CENSORSHIP OR DISCIPLINE..."}

The AAUP statement that "they should be free from institutional censorship or discipline" may ring hollow to faculty members who recognize themselves as operating in a special setting unlike that of other social media users. In fact, the very guidelines set forth by the AAUP include cautionary messages to faculty members, even for utterances made in our role as citizens rather than as faculty members. According to the AAUP, faculty members are advised to remember that their "special position in the community imposes special obligations. As scholars and educational officers, they should remember that the public may judge their profession and their institution by their utterances. Hence, they should at all times be accurate, should exercise appropriate restraint, should show respect for the opinions of others, and should make every effort to indicate that they are not speaking for the institution" (AAUP 1940).

Of course, professors are not the only professionals with obligations. The American Bar Association (2020) states that "A lawyer, as a member of the legal profession, is a representative of clients, an officer of the legal system and a public citizen having special responsibility for the quality of justice." Similarly, the Society of Professional Journalists (2019) states that members of the profession have "a special obligation to serve as watchdogs over public affairs and government."

Although they uphold the right of faculty to make extramural utterances, these guidelines actually restrict a faculty member's freedom as a mere citizen, imposing restrictions that the AAUP believes are appropriate for the special role of a member of the professoriate. Faculty members, therefore, are bound by expectations established not by their institution but rather by the principles of the organization set up to protect academic freedom. When we ask how institutions have the audacity to monitor the extramural utterances of faculty members, a good place to start is the AAUP principle that addresses and apparently sanctions these comments.

There is no doubt that institutions are involved with and concerned about the extramural utterances of their faculty. Why wouldn't they be? After all, the AAUP guidelines acknowledge the stake that institutions have in those extramural utterances. Because of their important and powerful constituencies, universities seek control of their image, message, and reputation and how they affect current and potential students and their families, alumni and donor base, community leaders, and state legislators. A misstep can bring harm to years of carefully cultivated work; naturally, they want to avoid such a prospect. Universities, therefore, are concerned about what members of their community say about them on social media; however, as Whittington (2019) noted, "An institution's brand should take account of the fact that colleges and universities are places where people voice controversial ideas, where competing ideas are welcome, and where ideas can be fearlessly debated, defended, and rejected." The question is not whether institutions have an interest in the social media contributions of faculty members but rather whether they have a right to exercise control of them. Therein lies the problem.

Actually, the AAUP (2018) provides guidance for what is going too far: "The controlling principle is that a faculty member's expression of opinion as a citizen cannot constitute grounds for dismissal unless it clearly demonstrates the faculty member's unfitness for his or her position." But, we sincerely ask, what constitutes unfitness? Is it sufficient that a faculty member's expressions disagree with what is considered the orthodoxy on his or her campus? Is it enough that a faculty member expresses his or her views in an uncivil, even rude manner? Is it behavior that is, like obscenity, difficult to define but we will know it when we see it? Academic-freedom scholar Whittington (2019) noted, "No doubt professors sometimes behave irresponsibly in public or 
voice ill-considered, mistaken, or even disgusting opinions. Nonetheless, institutions of higher education would be worse off if they regularly sought to censor such speech by members of the faculty."

In fact, deviation from orthodoxy seems to play a role in what institutions find acceptable. Many readers will recognize the case of Steven Salaita, whose job offer at the University of Illinois was rescinded when he sent out tweets critical of Israel. Because that political perspective was not acceptable to his new university, officials withdrew the job offer, commenting that his views would make it difficult or impossible for him to have civil conversations with those who disagreed with them (Wilson 2015a; 2015b).
In addition to these cases that involve deviation from campus orthodoxy, rude and controversial comments, and more seriously disturbing comments such as those about the Sandy Hook murders, there is another category of faculty expressions: on-campus matters involving students and, occasionally, other faculty members. These expressions comprise the category of "I just have to vent to someone about this mess" and often involve situations encountered in the classroom. Where better to do that than on social media? These cases sometimes are complicated by the inclusion of identifying information about students or other faculty members, which can have unfortunate results. To illus-

\section{What about the issue of a faculty member being rude, obnoxious, controversial, or vulgar? Do those qualities prove an unfitness to teach?}

There are other cases as well, such as the faculty member who blogged about her support of same-sex marriage, which was not an acceptable view at the university where she taught. Her online comments cost her continuing employment (Hatch 2017). In another case, a faculty member at Duke University spoke out about his views on groups integrating into American society. When he said online that he believed Asians have integrated into American society more effectively than African Americans, a Duke spokesperson said that the professor's "comments were noxious, offensive, and have no place in civil discourse" (Berenson 2015). Of great importance, however, is the fact that whereas the faculty member's remarks were offensive, the university still recognized his right to make them.

What about the issue of a faculty member being rude, obnoxious, controversial, or vulgar? Do those qualities prove an unfitness to teach? Recall the case of Otto Warmbier, the young man who was imprisoned and tortured in North Korea and who died shortly after being released. A faculty member commented that Warmbier had "gotten what he deserved," a remark picked up and widely distributed by Campus Reform (Bancalari 2017; Shugerman 2017). There also was the case of the faculty member who commented that for American democracy to survive, "Trump must hang"-a comment widely distributed by Breitbart News. Even a casual remark, perhaps an attempt at humor, can have a substantial negative effect, as evidenced by the faculty member who lost his job after saying on Twitter that Texas Republicans had gotten what they deserved with Hurricane Harvey (Phillips 2017; Quintana 2017).

Finally, are some posts simply so controversial and disturbing that we know they have crossed some type of undefined line and, in fact, meet the AAUP standard for dismissal? An illustrative case trate, consider this case from 2017 that involves a faculty member and a student disagreeing about a test question. The student argued that the question was racist and the teacher said it was not. As faculty members, we probably envision meeting with the student to discuss her ideas and reviewing our test content with the goal of resolving the issue. However, what if a faculty member is so upset or angry that she takes the situation to social media, perhaps ranting about the student and her perceived unfairness of it all? In the test-question case, the professor was removed from her classroom in the middle of the semester and fired (Lapin 2017).

A similar situation involved John McAdams of Marquette University, who posted online a conversation between a graduate and an undergraduate student on the topic of same-sex marriage, identifying the individuals involved. Professor McAdams was dismissed by the university; however, he took the matter to court and, after lengthy litigation, he won his case against the university and was reinstated in August 2018 (Friedersdorf 2015; Leef 2017; Lukianoff 2017; Moreno 2018).

\section{WHAT ABOUT OVERSEAS CAMPUSES?}

The complexities of academic freedom are further exacerbated when US universities open satellite campuses outside of the United States, often in places where academic freedom has no history or standing. According to the Cross-Border Education Research Team, US schools "run a total of 77 foreign-branch campuses," most of which are in China or the United Arab Emirates, neither of which has a record of support for academic freedom (Guo 2018). Whereas on campuses in the United States, university administrators are concerned about alumni support and institutional reputation, on

\section{Finally, are some posts simply so controversial and disturbing that we know they have crossed some type of undefined line and, in fact, meet the AAUP standard for dismissal?}

is that of James Tracy, whose focus was the massacre of children and teachers at Sandy Hook. Tracy took the position online that the massacre was a hoax and that the children were alive-a message he took to the parents of the murdered children as he criticized them on his blog post (Travis 2017). satellite campuses, they typically are concerned about what their host-country government officials think. In fact, cases already have surfaced that involve "Chinese government harassment and surveillance on campuses, visa denials, and pressures to censor or self-censor" (Human Rights Watch 2019). Additionally, Human 
Rights Watch (2019) reported that "the families of students have been threatened for things the students said in the classroom." In an effort to address threats to academic freedom from within China, Human Rights Watch (2019) proposed a 12-point code that recommends recordkeeping of incidents involving and speaking out for academic freedom. These issues are not confined to China; they involve other nations including Egypt, Russia, and Abu Dhabi (Ignatieff and Calhoun 2018). Therefore, it will remain an issue of importance for academic freedom for the foreseeable future. In Abu Dhabi, for example, numerous controversies have arisen about the New York University campus, including "unfair labor practices, academic freedom, and human rights violations" (Guo 2018). Writing for the Foundation on Individual Rights in Education, McLaughlin (2017) stated that "while universities are happy to offer promises of academic freedom overseas, they too often find it difficult to keep those promises when challenged."

The fact that Human Rights Watch proposed ways to meet challenges to academic freedom in China leads us to think that the AAUP may not have adequate power or resources to take on multiple breaches from satellite campuses, even though those campuses supposedly are administered by officials associated with the home site. It remains to be seen whether the AAUP's measured responses to cases within the United States will be effective when dealing with powerful government forces in nations that have no tradition of protecting academic freedom-and often no intention of doing so now.

\section{CONCLUSIONS: SUCH A COMPLICATED ISSUE!}

Here is what we know so far:

- The characteristics of social media have made it possible for comments of faculty members to be widely distributed without intermediaries assessing the content and without the writer's consent. Scholars are recognizing that social media is affecting government and society as users find their way to sites that support and augment their beliefs. These social media features appear to be increasing polarization and encouraging ever more strident comments by online participants. This means, of course, that the power of social media is enormous and unprecedented.

- Some institutions monitor the extramural utterances of their faculty members, choosing-in some cases-to respond. Inasmuch as AAUP guidelines state that such utterances cannot constitute a reason to punish the faculty member unless they expose his or her unfitness for the position, there would seem to be no reason for investigation or punishment for their extramural utterances except in the most obvious and offensive cases. The term "unfitness" remains undefined, which means that faculty members are at the mercy of their institution when they post to social media.

- There appear to be categories of utterances that spawn investigations and punishment, including taking a position on a controversial topic that is opposed to the acceptable view on campus; posting in a rude, uncivil manner; and posting about students and colleagues-sometimes including names and details of the issue. It is true that, occasionally, faculty members do make posts that are not only controversial or uncivil but also disturbing.

\section{CONCLUSION: A MODEST PROPOSAL}

In the interest of academic freedom for extramural utterances and mindful of the power of social media, I propose these two ideas:

1. Perhaps the AAUP would consider a discussion of its principles on extramural utterances because most faculty members are already mindful of their place at the institution and in the community. Current AAUP guidelines seemingly allow institutions to impose boundaries that may encroach on the First Amendment rights of faculty members. On many occasions, the AAUP has updated its guidelines; it may be time for another revision, given the impact of social media.

2. Perhaps the AAUP would be willing to struggle with a definition of what is sufficient to make faculty members "unfit" for their position. By providing such guidance, both faculty members and institutions would have a clearer sense of what is unacceptable behavior.

I believe these two ideas could safeguard protections for faculty members as they engage in expression as mere citizens rather than as faculty members, especially in this age of instant worldwide communication.

\section{REFERENCES}

American Association of University Professors (AAUP). 1940. "1940 Statement of Principles on Academic Freedom and Tenure." Available at www.aaup.org/ report/1940-statement-principles-academic-freedom-and-tenure. Accessed January 30, 2018.

American Association of University Professors (AAUP). 2018. "Civility." Available at www.aaup.org/issues/civility. Accessed November 6, 2018.

American Bar Association. 2020. "Model Rules of Professional Conduct: Preamble and Scope." Available at www.americanbar.org/groups/professional responsibility/publications/model_rules_of_professional_conduct/model_rules_ of_professional_conduct_preamble_scope. Accessed January 18, 2020.

Bancalari, Kellie. 2017. "Free Speech on Campus? Not for Adjunct Faculty, It Seems." USA Today College, August 29. Available at http://college.usatoday.com/2017/08/ 29/free-speech-on-campus-not-for-adjunct-faculty. Accessed February 12, 2018

Berenson, Tessa. 2015. "Duke Professor on Leave after Posting Racially Charged Comments." Time, May 18. Available at http://time.com/3882330/duke-professorracist-comments. Accessed February 9, 2018.

Briegas, Marta Torres, and Adrian Lorenzo Perez. 2018. "Fake News: The Figures and Solutions of a Global Phenomenon." BBVA, May 16. Available at www.bbva.com en/fake-news-the-figures-and-solutions-of-global-phenomenon. Accessed January 9, 2019.

Chemerinsky, Erwin, and Howard Gillman. 2017. Free Speech on Campus. New Haven, CT: Yale University Press.

Eady, Gregory, Jonathan Nagler, Andy Guess, Jan Zilinsky, and Joshua A. Tucker. 2019. "How Many People Live in Political Bubbles on Social Media? Evidence from Linked Survey and Twitter Data." Available at https://doi.org/10.1177/ 2158244019832705. Accessed October 22, 2019.

Friedersdorf, Conor. 2015. "Stripping a Professor of Tenure over a Blog Post." The Atlantic, February 9. Available at www.theatlantic.com/education/ archive/2015/o2/stripping-a-professor-of-tenure-over-a-blog-post/38528o. Accessed February 6, 2018

Guo, Quanzhi. 2018. “Top U.S. Colleges with Branches Overseas.” Forbes, August 21. Available at www.forbes.com/sites/quanzhiguo/2018/08/21/top-u-s-colleges-withbranches-overseas/\#59bdfd475cb4. Accessed October 30, 2019.

Hatch, Heidi. 2017. "BYU-Idaho Fires Adjunct Professor after LGBT Pride Month Post on Facebook.” KUTV, July 18. Available at http://kutv.com/news/local/ byu-idaho-fires-an-adjunct-professor-after-lgbt-pride-month-post-on-facebook. Accessed February 8, 2018.

Human Rights Watch. 2019. "China: Government Threats to Academic Freedom Abroad." Human Rights Watch, March 21. Available at www.hrw.org/news/ 
2019/03/21/china-government-threats-academic-freedom-abroad. Accessed October 22, 2019.

Ignatieff, Michael, and Craig Calhoun. 2018. "Insidious Threats to Academic Freedom in the US and Abroad. Academic Freedom and Authoritarian Populism: Lessons from the Front Line." Weatherhead Center for International Affairs, March 21. Cambridge, MA: Harvard University. Available at https://wcfia. harvard.edu/publications/centerpiece/spring2018/transcript_jodidi2018. Accessed October 21, 2019

Lapin, Tamar. 2017. "Professor Fired for Retaliating after Student Claims Test Question Is Racist.” New York Post, June 20. Available at https://nypost.com/2017 06/20/professor-fired-for-retaliating-after-student-claims-test-question-is-racist. Accessed February 7, 2018.

Leef, George. 2017. "Court Ruling Trashes Tenure, Opens the Door to 'Borking' of College Professors.” Available at www.forbes.com/sites/georgeleef/2017/05/30/ court-ruling-trashes-tenure-opens-the-door-to-borking-of-college-professors/ \#3231f 35 f57co. Accessed January 29, 2018.

Lukianoff, Greg. 2017. “The 10 Worst Colleges for Free Speech: 2016.” The Huffington Post, December 6. Available at www.huffingtonpost.com/greg-lukianoff/the-10worst-colleges-for_b_924300o.html. Accessed February 6, 2018.

McLaughlin, Sara. 2017. "On Overseas Satellite Campuses, Academic Freedom Is More Often Promised Than Practiced." Foundation for Individual Rights in Education, November 17. Available at www.thefire.org/about-us. Accessed October 21, 2019

Merriam-Webster Dictionary. 2019. Available at www.merriam-webster.com/ dictionary/social\%2omedia?src=search-dict-box. Accessed February 27, 2019.

Moreno, Ivan. 2018. "Following Court Ruling, Marquette Says It Will Reinstate Professor It Fired in Flap over Gay Marriage Debate.” Chicago Tribune, July 6. Available at www.chicagotribune.com/news/local/breaking/ct-met-marquetteuniversity-professor-court-decision-20180706-story.html. Accessed November $1,2018$.

Phillips, Kristine. 2017. "A University Professor Suggested Harvey Was Karma for Texas Republicans. Then, He Was Fired.” The Washington Post, August 30. Available at www.washingtonpost.com/news/grade-point/wp/2017/08/29/ university-fires-professor-who-suggested-harvey-was-karma-for-texas-republicans / ?utm_term=.cdga961c5e55. Accessed February 6, 2018.
Quintana, Chris. 2017. "Under Fire, These Professors Were Criticized by Their Colleges." The Chronicle of Higher Education, June 28. Available at www.chronicle.com/article/ Under-Fire-These-Professors/240457. Accessed January 29, 2018.

Shugerman, Emily. 2017. "Professor Fired after Saying Otto Warmbier Was a 'Clueless White Male' Who 'Got What He Deserved.”' The Independent, June 26 Available at www.independent.co.uk/news/world/americas/otto-warmbier-deathprofessor-facebook-post-north-korea-delaware-university-fired-a7809146.html. Accessed February 6, 2018.

Smith, Aaron, and Monica Anderson. 2018. "Social Media Use in 2018." Pew Research Center, March 1. Available at www.pewinternet.org/2018/03/01/social-media-usein-2018. Accessed January 8, 2019.

Society of Professional Journalists. 2014. "SPJ Code of Ethics." Available at www.spj org/ethicscode.asp. Accessed January 31, 2019.

Spohr, Dominic. 2017. "Fake News and Ideological Polarization: Filter Bubbles and Selective Exposure on Social Media." Business Information Review, August 23. Available at https://journals.sagepub.com/doi/full/10.1177/0266382117722446. Accessed October 17, 2019.

Travis, Scott. 2017. "Trial to Begin for Fired FAU Professor, Conspiracy Theorist James Tracy." Sun Sentinel, November 27. Available at www.sun-sentinel.com/ news/education/fl-james-tracy-trial-advance-20171127-story.html. Accessed February 8, 2018.

Whiteman, Honor. 2015. "Social Media: How Does It Affect our Mental Health and Well Being?" Medical News Today, June 1. Available at www.medicalnewstoday. com/articles/275361.php. Accessed January 8, 2019.

Whittington, Keith. 2019. "Academic Freedom and the Scope of Protections for Extramural Speech.” Academe. Available at www.aaup.org/article/academic-freedomand-scope-protections-extramural-speech?link_id=5\&can_id=490a8oce6b1ob68fo547 d92d84f22133\&source=email-new-culture-wars-5\&email_referrer=email_493895\& email_subject=new-culture-wars\#.XGbQlOhKiUk. Accessed February 15, 2019.

Wilson, John K. 2015a. "Academic Freedom and Extramural Utterances: The Leo Koch and Steven Salaita Cases at the University of Illinois." AAUP Journal of Academic Freedom, Vol. 6. Available at www.aaup.org/sites/default/files/ Wilson.pdf. Accessed February 21, 2018.

Wilson, John K. 2015b. "Academic Freedom and a Tale of Two Dismissals.” First Amendment Studies 49 (1): 5-7. 